\title{
Application of the Ecosystem Service Concept in Social-Ecological Systems-from Theory to Practice
}

\author{
Johannes Rüdisser ${ }^{1, *} \mathbb{C}$, Georg Leitinger ${ }^{1}(\mathbb{C})$ and Uta Schirpke ${ }^{1,2}(\mathbb{D}$ \\ 1 Department of Ecology, University of Innsbruck, Sternwartestrasse 15, A-6020 Innsbruck, Austria; \\ Georg.Leitinger@uibk.ac.at (G.L.); uta.schirpke@eurac.edu (U.S.) \\ 2 Institute for Alpine Environment, Eurac Research, Viale Druso 1, 39100 Bozen/Bolzano, Italy \\ * Correspondence: Johannes.Ruedisser@uibk.ac.at; Tel.: +43-512-507-51617
}

Received: 3 April 2020; Accepted: 7 April 2020; Published: 8 April 2020

\begin{abstract}
Ecological footprint analyses demonstrate that the world's more than 7.5 billion people consume multiple planets' worth of resources. To incite and evaluate societal changes for the sustainable use of the environment and its natural resources, the ecosystem service (ES) concept was developed more than 20 years ago. To ensure the sustainable provision of indispensable ES, the concept has been refined and enhanced, enabling its application across various temporal and spatial scales. However, evidence-based strategies and policies are needed to preserve biodiversity and natural capital in our changing world. This Special Issue comprises studies advancing the frameworks, concepts, and applications related to ES assessment, with a particular focus on social-ecological systems. To broadly apply the ES concept in different social-ecological systems, several key issues emerged: (1) ES-related definitions and procedures should be improved and standardized; (2) the complexity of the interactions in a social-ecological system must be recognized, and knowledge about spatial and temporal dynamics and interactions among multiple ESs must be deepened; and (3) communication about ES, considering cultural and stakeholder differences, must be increased.
\end{abstract}

Keywords: sustainability; spatial dynamics; communication; special issue; natural capital

\section{Introduction}

Human activities have caused several global developments, such as climate change, biodiversity loss, and ecosystem deterioration, which pose serious risks to the quality of life of people around the world [1]. These risks and the need for transformative changes are increasingly recognized by science [2] and society, which led to the formulation of the sustainable development goals (SDGs) adopted by the member states of the United Nations in 2015 [3]. These SDGs are an expression of a political will to globally adopt the concept of sustainable development. This concept integrates biodiversity conservation and human development, which have often been seen in conflict with each other [4].

While the recognition of nature's contributions to human welfare is not a new concept, it was the Millennium Ecosystem Assessment [5] that substantially contributed to the awareness and promotion of the sustainable use of natural resources. Since then, numerous scientific efforts have been undertaken to refine and enhance the ecosystem service (ES) concept to make it transferable, generalizable, and applicable across various temporal and spatial scales and to improve the implementation and evaluation of measures aiming at the sustainable use of ecosystems. While this has resulted in a still rapidly growing number of ES-related studies [6], shortcomings in geographic distribution, the coverage of ES categories, trade-off analyses, stakeholder involvement, relevance, and transferability still exist [7]. Although the general public is as yet not very aware of the ES concept and its linkages to biodiversity, 
an increasing number of stakeholders and policymakers have started to adopt it in policymaking practices [8].

As the ES concept focuses on the linkages between people and their environment, it integrates ecological and social aspects. Hence, it provides a suitable framework to a) understand specific aspects of the human-nature relationship, b) promote inter- and transdisciplinary research, c) facilitate a discussion about the trade-offs between services, and d) develop management strategies for ecosystems involving different stakeholder groups [9]. Its implementation in practice and integration in decision-making remains challenging, as many ES studies and assessment tools do not yet adequately address the requirements of decision makers [10]. To successfully implement the ES concept, one must take special care to refine and specify the related definitions and procedures.

The inseparable link between ecological and social systems emphasizes that ES assessments must consider both the complex relationships between ecosystem processes, structures, and capacities, and the distribution and assessment of the benefits between stakeholders with different needs and aspirations. The fact that the links between ecosystem processes and benefits for human well-being are multifaceted, non-linear, and dynamic [11] has raised the need for a Special Issue on the 'Application of the Ecosystem Service Concept in Social-Ecological Systems-from Theory to Practice'. The included studies show that despite an almost infinite number of frameworks for the comprehensive description of social-ecological systems in the scientific literature, great progress in the application of the selected frameworks is becoming apparent.

This Special Issue includes studies that advance the terminology, frameworks, concepts, and applications related to ES assessment, with a particular focus on social-ecological systems. The 14 published articles are authored by 68 scholars from 15 countries who come from different disciplines, such as biology, ecology, agricultural science, forestry, geography, environmental science, sociology, and economics. The presented applications and case studies range from the local to international scale and include a variety of different social-ecological systems, such as alpine farms, river basins, rural communities, an oasis, islands, the European Alps, a metropolitan area, and a marine basin. With a few exceptions, all examine ES bundles, and although most studies refer to distinct case study areas, the presented frameworks and conceptual considerations are largely transferable to other regions.

In the following, we summarize the insights and report the limitations and unresolved challenges to broadly applying the ES concept in different social-ecological systems and then provide recommendations to enhance the contributions of the ES concept to the development and execution of sustainable policies and environmental conservation strategies. These considerations are based on the results of this Special Issue and our own research.

\section{Insights Gained}

The complex relationship between human activities, ecosystem properties, and ES can be described and analyzed in various ways. One approach is to focus on spatial characteristics and correlation. This was done by Chen et al. (contribution 2, see below), who found a strong correlation between topographic gradients, land-use patterns, and ES provisions. Wei et al. (contribution 14) identified land-use changes as the main driver for changes in ES provisions in the Manas region in China and spatially delineated regions with similar ES bundles using cluster analysis. Lorilla et al. (contribution 6) assessed the spatio-temporal dynamics of ES supply on the Ionian Islands in Greece, which seem to be influenced by agriculture, land abandonment, increasing tourism, and the occurrence of fires. Riechers et al. (contribution 11) focused on the demand side of cultural ES provided by green spaces along an urbanization gradient in Berlin, Germany. They identified two bundles of cultural ES in urban vs. periurban areas. They found that while higher population density is positively correlated with a higher valuation of cultural ESs related to social interaction and cultural diversity, the opposite is true for ESs related to education, recreation, and aesthetic appreciation.

In most social-ecological systems, land-use and its changes substantially influence the provision of ESs [12]. Hence, the comprehensive analysis of land-use demands an inter- or even transdisciplinary 
approach and the application of both social and natural science methods. While Selomane et al. (contribution 13) proposed to better harness the insights gained from social-ecological system studies and apply them to monitoring and indicator development for the sustainable development goals, Schirpke et al. (contribution 12) proposed applying sustainability and ES concepts in a complementary way. The development of sustainable management strategies based on ES assessments must engage with the evolved and affected local communities while considering cultural differences and profiting from indigenous or local knowledge (contribution 4). When applying ES concepts in policymaking and planning, it is also crucial to consider spatial differences in both the supply and the demand side. This can be a demanding task due to the huge number of individual ESs and their complex interactions [13]. A possible solution to tackle this complexity-as demonstrated by various studies in this Special Issue (contributions 6, 11, and 14)-is the application of ES bundles. Social-ecological systems that have a defined biophysical border and can be considered a more or less closed system, such as islands (contributions 6 and 9), oases (contribution 14), mountain villages (contribution 8), and marine basins (contribution 5), seem to provide suitable "real life laboratories" for case studies and framework development. While Accastello et al. (contribution 1) and Newman et al. (contribution 9) worked on conceptual framework development and improvement, Jiang et al. (contribution 3) discussed an approach to analyze payment for ES programs.

\section{Identified Limitations}

While the supply (and use) of many ESs can be assessed biophysically, the demand for ESs is often substantially influenced by the perception of ESs [14]. This is especially true for cultural ESs. Various studies have reported the diverging perceptions of the demand, importance, and value of ESs among different stakeholders and users (contributions 4, 10, and 11). Diverging perceptions of ESs can be caused by knowledge gaps, as identified by Paschoud et al. (contribution 10), among tourists and farmers on farms in the Italian Alps or by the diverging stakeholders' demands for ESs [15] and the valuation of their benefits [16,17].

While value attributions by humans turn an ecosystem function into a desired ES (potential), which is crucial for the ES concept, Nassl and Löffler (contribution 8) noted that the use of the term 'value' (assigned values for an ES) is different in the social-ecological system literature, where it focuses more on the values of people (held values). While assigned values delimitate the relative importance or worth of an ES, this concept often falls short of defining how societal values manifest in societies and hence shape natural resource use.

\section{Recommendations to Apply the Ecosystem Service Concept in Social-Ecological Systems}

To enhance the contributions of the ES concept to the development and execution of sustainable policies and environmental conservation strategies in social-ecological systems, the following recommendations can be derived from the contributions of this Special Issue:

- To ensure that measures to protect ESs are applied and accepted by the public and stakeholders, it is important to improve communication about ESs, especially for ESs that are less recognized or poorly understood (contributions 4, 5, 6, and 10), e.g., by applying social learning, as described by Lopez-Rodriguez et al. (contribution 5).

- The understanding of spatial and temporal dynamics and the interactions among multiple ESs must be improved to provide useful and applicable information for decision making (contribution 6).

- This requires a deeper knowledge of how social-economic factors influence the provision of ESs (contribution 5), taking into account different cultural contexts [18].

- Insights from studies about social-ecological systems (considering feedback, non-linearity, system resilience, etc.) should be harnessed to develop and apply more dynamic and systemic indicators and monitoring systems (contributions 8 and 13). 
- To evaluate and improve the applicability and effectiveness of payments for ecosystem services (PESs) (contribution 3), it is important to a) precisely describe the relationships between ES provisions and their beneficiaries, $b$ ) develop suitable and standardized ES indicators and ES quantification methods [18], and c) iteratively improve PES schemes to optimize their output and enhance the desired ES provisions.

- Although PESs seem to be an important tool to promote the implementation and application of the ES concept and to enhance its impact, it should be recognized that PESs are only one possible application strategy among many others. Therefore, the development of applications, frameworks, and combinations of ESs should not be limited to PESs.

\section{List of Contributions}

1. Accastello, C.; Blanc, S.; Brun, F.A Framework for the Integration of Nature-Based Solutions into Environmental Risk Management Strategies. Sustainability 2019, 11, 489; doi:10.3390/su11020489.

2. Chen, Y.; Xu, N.; Yu, Q.; Guo, L. Ecosystem Service Response to Human Disturbance in the Yangtze River Economic Belt: A Case of Western Hunan, China. Sustainability 2020, 12, 465; doi:10.3390/su12020465.

3. Jiang, B.; Chen, Y.; Bai, Y.; Xu, X. Supply-Demand Coupling Mechanisms for Policy Design. Sustainability 2019, 11, 5760; doi:10.3390/su11205760.

4. Lhoest, S.; Vermeulen, C.; Fayolle, A.; Jamar, P.; Hette, S.; Nkodo, A.; Maréchal, K.; Dufrêne, M.; Meyfroidt, P. Quantifying the Use of Forest Ecosystem Services by Local Populations in Southeastern Cameroon. Sustainability 2020, 12, 2505; doi:10.3390/su12062505

5. López-Rodríguez, M.; Cabello, J.; Castro, H.; Rodríguez, J. Social Learning for Facilitating Dialogue and Understanding of the Ecosystem Services Approach: Lessons from a Cross-Border Experience in the Alboran Marine Basin. Sustainability 2019, 11, 5239; doi:10.3390/su11195239.

6. Lorilla, R.; Poirazidis, K.; Kalogirou, S.; Detsis, V.; Martinis, A. Assessment of the Spatial Dynamics and Interactions among Multiple Ecosystem Services to Promote Effective Policy Making across Mediterranean Island Landscapes. Sustainability 2018, 10, 3285; doi:10.3390/su10093285.

7. Meisch, C.; Schirpke, U.; Huber, L.; Rüdisser, J.; Tappeiner, U. Assessing Freshwater Provision and Consumption in the Alpine Space Applying the Ecosystem Service Concept. Sustainability 2019, 11, 1131; doi:10.3390/su11041131.

8. Nassl, M.; Löffler, J. How Societal Values Determine the Local Use of Forest Resources-Findings from the Rural Community Kegong (Northwest Yunnan, China). Sustainability 2019, 11, 3447; doi:10.3390/su11123447.

9. Newman, R.; Capitani, C.; Courtney-Mustaphi, C.; Thorn, J.; Kariuki, R.; Enns, C.; Marchant, R. Integrating Insights from Social-Ecological Interactions into Sustainable Land Use Change Scenarios for Small Islands in the Western Indian Ocean. Sustainability 2020, 12, 1340; doi:10.3390/su12041340.

10. Pachoud, C.; Da Re, R.; Ramanzin, M.; Bovolenta, S.; Gianelle, D.; Sturaro, E. Tourists and Local Stakeholders' Perception of Ecosystem Services Provided by Summer Farms in the Eastern Italian Alps. Sustainability 2020, 12, 1095; doi:10.3390/su12031095.

11. Riechers, M.; Strack, M.; Barkmann, J.; Tscharntke, T. Cultural Ecosystem Services Provided by Urban Green Change along an Urban-Periurban Gradient. Sustainability 2019, 11, 645; doi:10.3390/su11030645.

12. Schirpke, U.; Egarter Vigl, L.; Tasser, E.; Tappeiner, U. Analyzing Spatial Congruencies and Mismatches between Supply, Demand and Flow of Ecosystem Services and Sustainable Development. Sustainability 2019, 11, 2227; doi:10.3390/su11082227.

13. Selomane, O.; Reyers, B.; Biggs, R.; Hamann, M. Harnessing Insights from Social-Ecological Systems Research for Monitoring Sustainable Development. Sustainability 2019, 11, 1190; doi:10.3390/su11041190. 
14. Wei, H.; Fan, W.; Lu, N.; Xu, Z.; Liu, H.; Chen, W.; Ulgiati, S.; Wang, X.; Dong, X. Integrating Biophysical and Sociocultural Methods for Identifying the Relationships between Ecosystem Services and Land Use Change: Insights from an Oasis Area. Sustainability 2019, 11, 2598; doi:10.3390/su11092598.

Author Contributions: Conceptualization, J.R., U.S. and G.L.; Writing-original draft preparation, J.R.; writing-review and editing, J.R., G.L. and U.S. All authors have read and agreed to the published version of the manuscript.

Funding: This research received no external funding

Acknowledgments: G.L.: U.S. and J.R. are members of the research area 'Mountain Regions' at the University of Innsbruck.

Conflicts of Interest: The authors declare no conflict of interest.

\section{References}

1. Summary for Policymakers of the Global Assessment Report on Biodiversity and Ecosystem Services of the Intergovernmental Science-Policy Platform on Biodiversity and Ecosystem Services; IPBES: Bonn, Germany, 2019.

2. Díaz, S.; Settele, J.; Brondízio, E.S.; Ngo, H.T.; Agard, J.; Arneth, A.; Balvanera, P.; Brauman, K.A.; Butchart, S.H.M.; Chan, K.M.A.; et al. Pervasive human-driven decline of life on Earth points to the need for transformative change. Science 2019, 366, eaax3100. [CrossRef] [PubMed]

3. Gupta, J.; Vegelin, C. Sustainable development goals and inclusive development. Int. Environ. Agreem. 2016, 16, 433-448. [CrossRef]

4. Niesenbaum, R.A. The Integration of Conservation, Biodiversity, and Sustainability. Sustainability 2019, 11, 4676. [CrossRef]

5. Millennium Ecosystem Assessment. Ecosystems and Human Well-Being: Biodiversity Synthesis; World Resources Institute: Washington, DC, USA, 2005.

6. McDonough, K.; Hutchinson, S.; Moore, T.; Hutchinson, J.S. Analysis of publication trends in ecosystem services research. Ecosyst. Serv. 2017, 25, 82-88. [CrossRef]

7. Lautenbach, S.; Mupepele, A.C.; Dormann, C.F.; Lee, H.; Schmidt, S.; Scholte, S.S.; Seppelt, R.; van Teeffelen, A.J.; Verhagen, W.; Volk, M. Blind spots in ecosystem services research and challenges for implementation. Reg. Environ. Chang. 2019, 19, 2151-2172. [CrossRef]

8. Robinne, F.-N.; Gallagher, L.; Bréthaut, C.; Schlaepfer, M.A. A novel tool for measuring the penetration of the ecosystem service concept into public policy. Ecosyst. Serv. 2019, 36, 100914. [CrossRef]

9. Schröter, M.; Ring, I.; Schröter-Schlaack, C.; Bonn, A. The Ecosystem Service Concept: Linking Ecosystems and Human Wellbeing. In Atlas of Ecosystem Services: Drivers, Risks, and Societal Responses; Schröter, M., Bonn, A., Klotz, S., Seppelt, R., Baessler, C., Eds.; Springer: Berlin/Heidelberg, Germany, 2019; pp. 7-11. ISBN 978-3-319-96228-3.

10. Grêt-Regamey, A.; Sirén, E.; Brunner, S.H.; Weibel, B. Review of decision support tools to operationalize the ecosystem services concept. Ecosyst. Serv. 2017, 26, 306-315. [CrossRef]

11. Costanza, R.; de Groot, R.; Braat, L.; Kubiszewski, I.; Fioramonti, L.; Sutton, P.; Farber, S.; Grasso, M. Twenty years of ecosystem services: How far have we come and how far do we still need to go? Ecosyst. Serv. 2017, 28, 1-16. [CrossRef]

12. Egarter Vigl, L.; Schirpke, U.; Tasser, E.; Tappeiner, U. Linking long-term landscape dynamics to the multiple interactions among ecosystem services in the European Alps. Landsc. Ecol. 2016, 31, 1903-1918. [CrossRef]

13. Schirpke, U.; Candiago, S.; Egarter Vigl, L.; Jäger, H.; Labadini, A.; Marsoner, T.; Meisch, C.; Tasser, E.; Tappeiner, U. Integrating supply, flow and demand to enhance the understanding of interactions among multiple ecosystem services. Sci. Total Environ. 2019, 651, 928-941. [CrossRef] [PubMed]

14. Haida, C.; Rüdisser, J.; Tappeiner, U. Ecosystem services in mountain regions: experts' perceptions and research intensity. Reg. Environ. Chang. 2016, 16, 1989-2014. [CrossRef]

15. Zoderer, B.M.; Tasser, E.; Carver, S.; Tappeiner, U. Stakeholder perspectives on ecosystem service supply and ecosystem service demand bundles. Ecosyst. Serv. 2019, 37, 100938. [CrossRef]

16. Yang, Y.E.; Passarelli, S.; Lovell, R.J.; Ringler, C. Gendered perspectives of ecosystem services: A systematic review. Ecosyst. Serv. 2018, 31, 58-67. [CrossRef] 
17. Fagerholm, N.; Torralba, M.; Moreno, G.; Girardello, M.; Herzog, F.; Aviron, S.; Burgess, P.; Crous-Duran, J.; Ferreiro-Domínguez, N.; Graves, A.; et al. Cross-site analysis of perceived ecosystem service benefits in multifunctional landscapes. Glob. Environ. Chang. 2019, 56, 134-147. [CrossRef]

18. Ainscough, J.; de Vries Lentsch, A.; Metzger, M.; Rounsevell, M.; Schröter, M.; Delbaere, B.; de Groot, R.; Staes, J. Navigating pluralism: Understanding perceptions of the ecosystem services concept. Ecosyst. Serv. 2019, 36, 100892. [CrossRef]

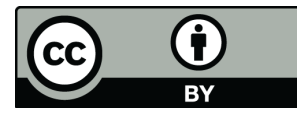

(C) 2020 by the authors. Licensee MDPI, Basel, Switzerland. This article is an open access article distributed under the terms and conditions of the Creative Commons Attribution (CC BY) license (http://creativecommons.org/licenses/by/4.0/). 